\title{
The Benefit of Belt and Road Initiative for Central Africa and China: A Case Study of Sub-Saharan African Countries
}

\author{
Ines Pamela Nguembi ${ }^{1}$, Zhang Yanrong ${ }^{1} \&$ Haidar Salaheldeen Abdalla ${ }^{2}$ \\ ${ }^{1}$ College of Financial and Economics, Gansu Agricultural University, Lanzhou City, Gansu Province, China \\ ${ }^{2}$ Agricultural Research Corporation, Ad-Damer, Sudan \\ Correspondence: Zhang Yanrong, College of Financial and Economics, Gansu Agricultural University, Lanzhou \\ City, Gansu Province, 73000, China. E-mail: zhangyr@gsau.edu.cn
}

Received: March 9, 2021

Accepted: April 9, 2021

Online Published: April 25, 2021

doi:10.5539/ijef.v13n5p105

URL: https://doi.org/10.5539/ijef.v13n5p105

\begin{abstract}
On a historical account, the apparent lack of documented economic data (accurate information) on the research budget and flexible schedule hinders economic growth and development. When the gravity model has been used for analysis a positive statistically important relationship has been found between transport facilities, continuity, and two-sided trade. However, the connection between transport facilities, continuity, and bilateral commerce on one hand and available documented economic data or information on another hand was missing. To determine how the availability of standard documented economic data or information squeezed economic growth and development as well as the relevance of this relationship; the authors analyzed this relationship. The BRI, Chinas' majestic idea of an economic belt created from the old road, covers almost all routes across Asia, Europe, and Africa. In the BRI area, the development of a sea, air, and road transport link among trading partners are relevant with a big scale influence on perfecting commerce. This brings to the fore, the second-most important influence, which is a testament to the road, sea transport, and number consistency. Also, transport service quality which has an important influence on bilateral commerce was studied. Our results purposes and guidance are that a standard investment in roads; total commerce in the BRI member countries (the central African countries (CAC) included) could become more valuable. Hence, perfecting transport facilities could lead to a win-win situation with a strong influence on commerce.
\end{abstract}

Keywords: BRI, China, CAC, trade areas, transportation

\section{Introduction}

BRI is a go-getting transformational plan of China to enhance connectivity and trade flow between Asia, Europe, and Africa (Lim et al., 2018). The BRI is a transport facilities project that has been created to influence the lives of about 4.4 billion people with a total GDP that amounted to US\$21 trillion. Such massive transport projects are not new, illustrations can be made from the American Gilded Era when road lines were constructed to link different areas together, with decreased transport cost, catalyzing spread of modern goods, encouraging economic flow, investment, and providing job opportunities ( $\mathrm{Lu}$ et al., 2018).

Before ten years, international trade and cooperation had skipped a vital role in whole African economic development in particular East Africa. Deloitte stated that Africa development projects particularly in construction have yearly increased by $59.1 \%$ and their total value increased by $53.3 \%$. The total number of projects in East Africa has reached about 139 as the biggest member in BRI. However, about 43 African countries out of 54 undertook the BRI project, although North Africa worth the largest of the benefits that amounted to about US\$148.3 billion. In Egypt, the projects were valued at about US\$79.2 billion as the most valuable ones in the continent content of about forty-six of construction that equivalent to about of the total projects in Africa. Therefore, Egypt leading the African continent in terms of infrastructural projects. Coming next to Egypt South Africa followed by Nigeria. In 2018 Deloitte analysis ranged the majority of the BRI constructions between US\$50m-US\$500m which was considered as a lower value range. In summary, a sum of 80 structured projects their values were exceeded US $\$ 1.1 \mathrm{bn}$, among them about 14 projects was valued greater than US\$10bn. This delivery goes coinciding with the 2018 Construction Trends Report on structuring, financing, and delivering huge projects for the African continent. Abe et al. (2009) stated that the two most vital economic divisions where massive investments are made in construction projects are oil and gas; and energy and power 
segments. According to Rolland (2017) structure projects in the fields of oil and power sectors valued by about US\$62 Billion about $13.0 \%$ of the African projects under BRI.

Das, (2017) cited that there are major corridors in BRI projects that comprise of the following: China-Mongolia-Russia, China-Central Asia-Western China-Pakistan, Bangladesh-China-India-Myanmar, and Indochina Peninsula. These networks routes, bridges, rivers, pipelines information highways case, sea, air linking industrial clusters, comprise maritime components.

\section{Research Objectives}

The main objective of our research is to trace the effect of achieving multi-modal transport continuity on multilateral commerce in the BRI zones in specifically the Central Africa countries. Both qualitative and quantitative analyses were used to reach the objective in question. Firstly, to identify potential obstacles to these transnational projects under the BRI; literature reviews and interviews were used. Nonetheless, the results from task factors were included to stretch the model. Secondly, we develop an econometric context to measure the accumulated facilities of the BRI projects. In predicting the reliability of the effect of transport facilities, we discussed the model and induced it to chains of policy script tests.

\section{Background}

\subsection{Some Graphs Showing the Trend of Growth in Both African Countries Under BRI and Those Without BRI}

Both figures one and two below showed trade composition in Africa in the year 2016. Nevertheless, the biggest share country worldwide in trade with African is China. Statistically, Chinese-African trade was estimated at US\$ 170 billion in 2017. Chinese export to Africa and Chinese import from Africa were US\$ 94.74 and US\$ 75.26, respectively, with a trade surplus estimated at US\$ 19.48 in the favor of China (Statistics, 2018). Only five African countries their trade balances were positive signs with China. So almost all African countries are structurally suffering from trade beneficial with China. The bulk (70\%) of Sub-Saharan African export to China was fuel and metal and mineral products raw material whilst China exports to these countries ready made commodities (Chen \& Nord, 2017).

The mentioned trade structure between China and Africa makes China's economy conditionally grown. However, the case of Sub-Saharan African raw materials exporters demonstrates the unbalanced trade; that African traders are relying on the international prices of raw resources. However, the slowing of Chinese economy and lower prices for raw goods in 2015-2016, negatively affected the value of Chinese-African trade. Both Figures 1 and 2 show the trade composition in Africa.

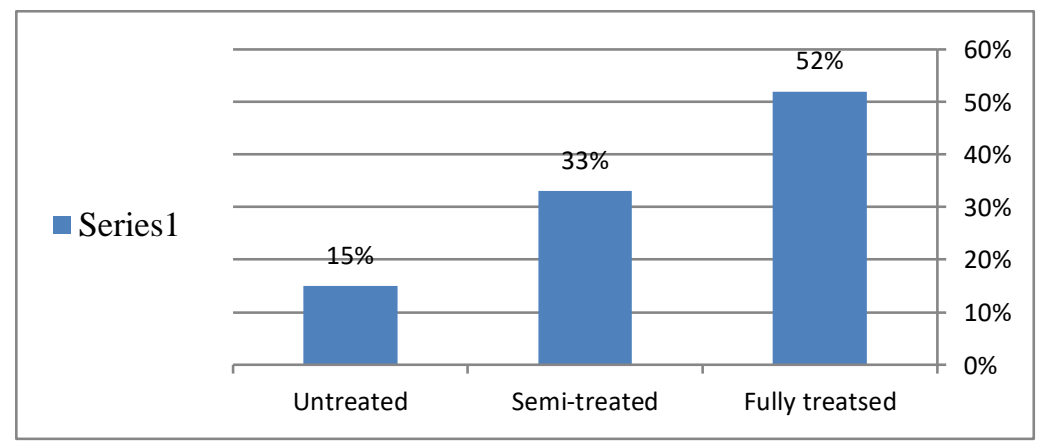

Figure 1. Commerce configuration in Africa, 2016 (Import)

Source: UN COMTRADE (database).

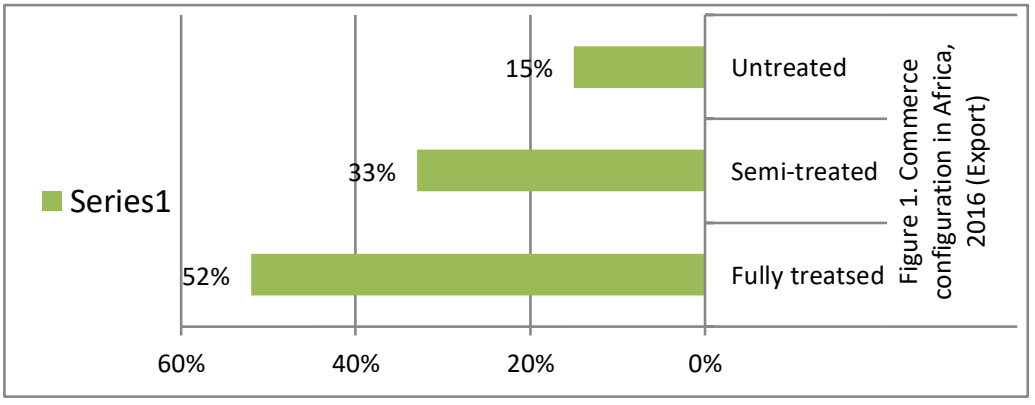

Figure 2. Commerce configuration in Africa, 2016 (Export) 


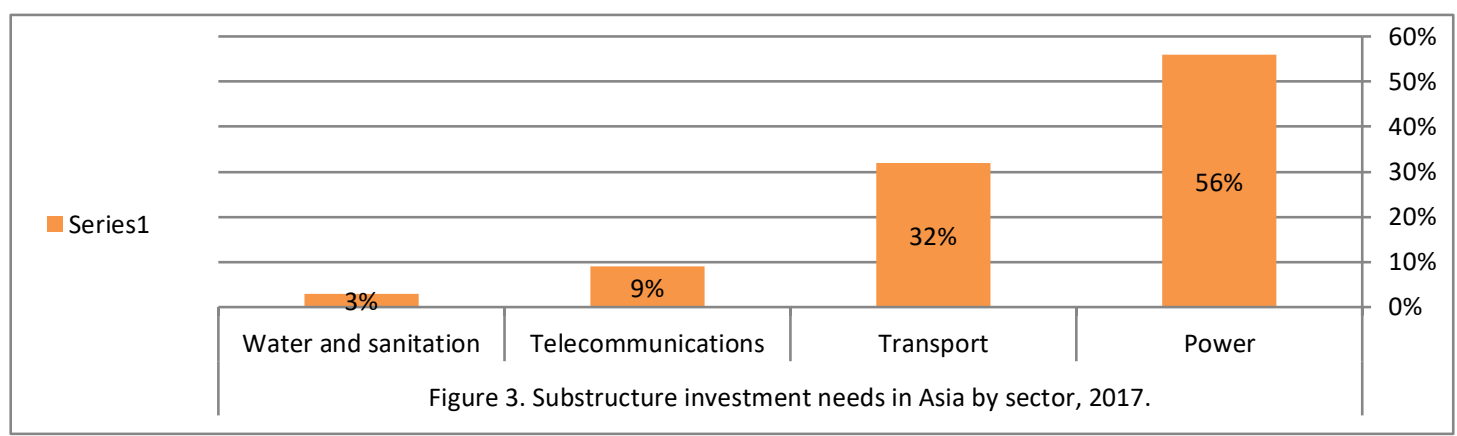

Figure 3. Substructure investment needs in Asia by sector, 2017

Source: ADB, 2017.

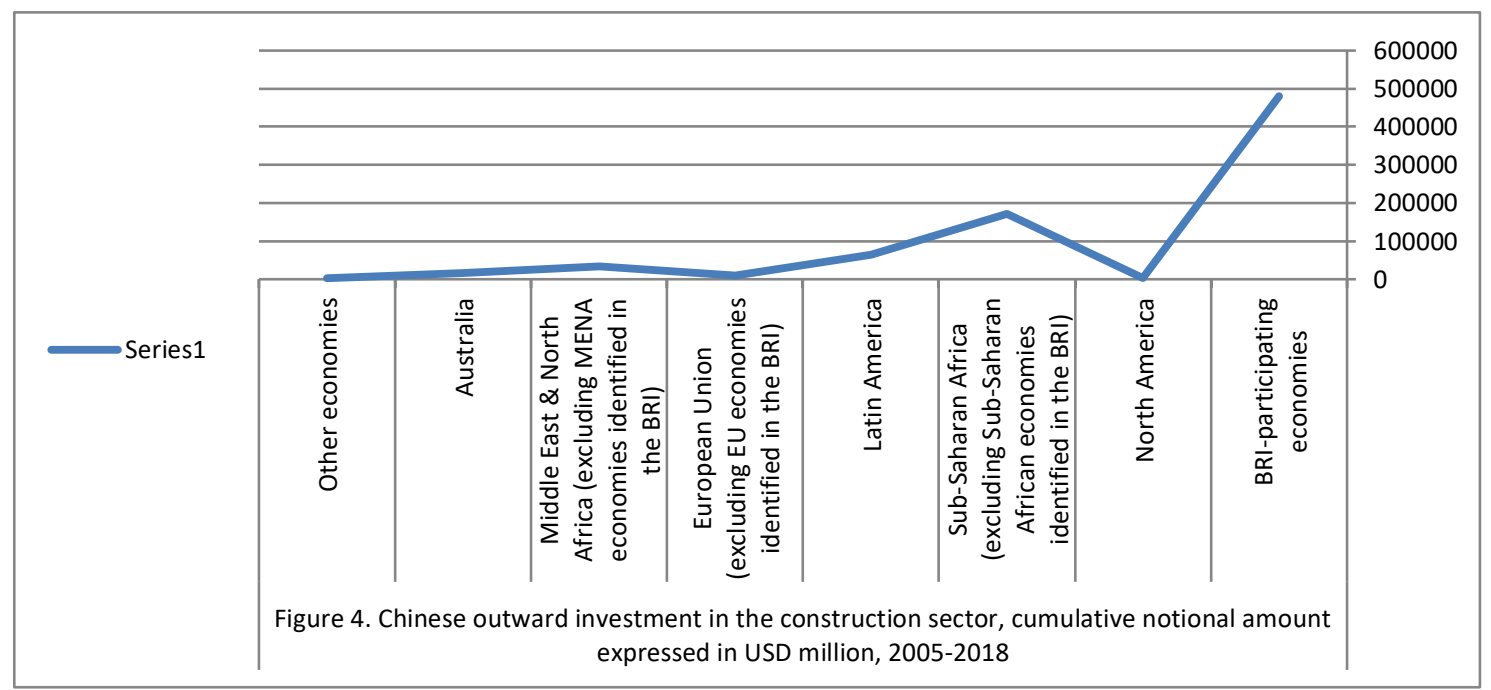

Figure 4. Chinese outward investment in the construction sector, cumulative notional amount expressed in USD million, 2005-2018

Source: http://dx.doi.org/10.1787/888933786382.

\subsection{China Benefits and Problems from BRI}

China has domestic and international benefits from BRI. However, the domestics ones include Trade and investment; energy and natural resources; and issues surrounding Taiwan passage. On the other hand, the international benefits of BRI for China content: China used its culture and influence to pursue African countries to trade with China rather than the use of war Soft Power. This soft power has been drastically increased in Africa; China grabbed the chance of the global economic recovery to the internationalization of renminbi at the same time they internationalized their factories (Zhongyan, 2019); and the OBOR enables China to play a bigger role in global governance; as a part of the global agenda. However, the problems were included the following ones: more than ten thousand Chinese enterprises are going out to invest in Africa making good business, but there are facing many problems. There are many Chinese state0owned enterprises $\left(\mathrm{SOE}_{\mathrm{s}}\right)$ and Chinese private enterprises that greatly varied in their goals. They take into consideration both the financial incremental performance and non-financial incremental performance. View of Chinese $\mathrm{SOE}_{\mathrm{s}}$ had a margin of profit of more than $20 \%$ whereas, $25 \%$ of them realized some losses (Sun, 2017). Nonetheless, some $\mathrm{SOE}_{\mathrm{s}}$ lack clear strategic planning, deployment as well as research programs. In addition to they didn't evaluate their market's investment before they starting operations; that may cause them some failures in BRI areas.

\subsection{Benefits of BRI for Africa and Risks}

BRI has many benefits for African states. At the beginning of 2016, a Memorandum of understanding on the BRI was signed between China and Egypt, in case to widen the Suez Canal over the coming ten years. The project cost was estimated at US\$ 230 million which was financed by China (Bagwandeen, 2017). However, the Suez project generates about ten thousand careers for Egyptian people. 
In the Djibouti case, the first Chinese abroad military base and container terminal in the port of Dolareh had been built by the Chinese government; to be among-st many foreign military bases in Djibouti, where the USA and some European countries have positioned the soldiers. That is to be one of the initiatives that emerged from the China-Africa Cooperation Beijing Action Plan (2019-2021). Forum (2018) stated that: "to progress the current global legal system; the stakeholders of the project (China and African countries) should have to reinforce interactions and collaboration in semi-governance, improve joint trust and exchanges in this admiration, provide legal support and guarantee for China-Africa cooperation and to cooperate on the BRI, and work together.".

Despite their incorporation in BRI, but Kenya and Ethiopia benefited more from China. However, China constituted a new Mombasa-Nairobi railroad for Kenya which was considered the biggest structure investment since their freedom. In the future, it may link Kenya with Uganda and it can link the Indian Ocean to other countries such as Rwanda, Burundi, and the Democratic Republic of the Congo, resulting in expansion of the geographical opportunity of the BRI projects. Nevertheless, Kenya gained from this railway the following: growing GDP by about $1.5 \%$, creates about 46,000 occupations for the Kenyan residents, and a $40 \%$ reduction in transport costs (Xianfa, 2018).

For the Ethiopian side, on the $1^{\text {st }}$ January 2018, China begins to build a new Addis Ababa-Djibouti railway line. Moneywise, this project was considered as largest of China's projects in Africa that was because Chinese banks provided about US\$ 3.3 billion to be established. Further, this railroad may link Ethiopia to the Republic of South Sudan (Kiedy, 2018).

BRI has many risks for African states. For example, high misuse or poor of the funded structure may result from overrating the good influences or benefits of infrastructural projects themselves. However, a highly idle project was Hambantota Port in Sri Lanka that built by China. Although the port hasn't container traffic, Sri Lanka had to give China a 99-year lease for debt relief. The second example was the Mattala Rajapaska International Airport in Sri Lanka that planed to carry a million passengers yearly, but it was called off for its big losses.

\section{Literature Review}

\subsection{Good Transport Facilities Facilitate Commerce Expansion}

The international commerce theory defines transportation costs as the alterations between make commerce and non-commerce goods. So the transportation costs can be treated as exogenous variables of the commerce models that depending on geographical factors. Rationally, that cost of transport may rely on the quality of transportation services. So to predict the costs of transportation we can use transport facilities across states as a guide. Nonetheless, in competitiveness transport facilities can be used to excuse for variances. Different ways can be used to clear out the cost of transport. The cost for a certain type of transportation such as seaport, shipping, and route, etc. can be disclosed as a direct measure or be resolute as costs per mile or kilometer. However, a decline in commodities above the past decades due to conceivable evidence in transportation facilities is worth documenting. Hummels (1999) also cited that the cost of air freight reduced by a factor of about 12.5 in the 1950s and the 2000s, while freight cost continued in place. Glaeser Kohlhase (2004) explored that the cost of shipping and route transportation diminished by a factor of about 8 over 10 years. A similar finding was achieved by Redding Turner (2015); that the transportation cost per ton-mile of (sea, air, and road transport) cargo cheap from about US\$0.2 1890 to US\$0.02 in 2000.

Moreover, the valuable transportation facilities can affect the cost of transport. The countrywide transport facilities represented $40 \%$ of transport costs for coastal countries, whereas national and transit country transport facilities accounted for sixty percent of transportation costs for non-coastal states Limão (2001). Also, the $25^{\text {th }}$ to the $75^{\text {th }}$ percentile conceivable that made by witnesses in route, sea, and air transport facilities; was predictable to overwhelmed more than half the disadvantages of being blocked-in states. Clark et al. (2004) cited that the cost of sea transport to and from the United States was equal to about $5.25 \%$ of the value of freight, so port efficacy can be donated hugely to the total cost. They estimated that worsening in seaport value from the $75^{\text {th }}$ to the $25^{\text {th }}$ percentile higher freight cost by $12 \%$.

The very serious thing to a company that hires activities and has a supply network; is that transportation is a third element factor. However, an equal to a day saved journey times; is that when the process reduce the tariff rates by about 0.4 to $1 \%$ and 0.8 to $1.5 \%$ for exports and imports respectively, Hummels (2007). In part when we calculate the remoteness between dealing allies we get the provision time but more notably between the geography and the quality of transportation capacity. A good example is that a meager incompetent anchorage handling processes can result in long deferrals that do not necessarily in reflecting the monetary costs of transportation. The means of wasting time in waiting at a seaport that has been calculated by Wilson (2003); this could make a vehicle traveling of about $1,600 \mathrm{~km}$ overland. These interruptions can be attributed to both poor 
seaports and bureaucratic procedures at ports.

\subsection{African Countries Involved in the BRI and Their Date of Integration}

Since the provision of US\$10 billion in 2015 by China Exim bank to structure projects in Egypt; the BRI scheme has been started in Africa. However, it the first African state that joined BRI agreements in Egypt. In June 2017, many African states were joined to BRI as forthcoming members these countries include South Africa, the Republic of Sudan, and Madagascar. Later in 2019, the group embraced some African states like Tunisia, Guinea, and Côte d'Ivoire. However, BRI is focusing on the Horn of Africa countries, namely: Kenya, Egypt, Djibouti, Tanzania, and Ethiopia, and then Nigeria, Cameroon, and Namibia were remarked as an expansion to the BRI scheme.

\subsection{BRI Gain for African Countries}

African continent gains a lot from BRI. In East Africa BRI seem to be progress in infrastructure building especially roads, highway, and railway connectivity, that implemented by Chinese companies. The Republic of Kenya achieves many constructions from BRI that include the following: a building of a modern seaport at Lamu; the standard gauge railway structure; and the enhancement of Mombasa harbor. Nonetheless, the structure of the pipeline that links Ugandan and South Sudan oilfields to Kenyan ports will be the coming project for Kenya. In Djibouti, the benefits include transportation of drinking water from Ethiopia to Djibouti through a pipeline that costs approximately three hundred million dollars. The provision of $\$ 4$ billion to modernize the $752.7 \mathrm{~km}$ Ethiopia-Djibouti Railway, with the Ethiopian section costing \$3.4 billion and China's Exim Bank will bear about seventy percent of the total cost of this project. Nonetheless, the African gateway for Europe and to link Africa to both Europe and Asia through the Mediterranean Sea are reachable through the Suez Canal; all that will be achieved by neighboring Djibouti to Egypt.

\subsection{Objective of BRI for China}

The main objectives of the BRI to China were described through issuing an action strategy by the Chinese government, in March 2015. First: China has to close all aspects of the viable growth for itself and including more balanced regional growth. Second: the country has to promote its manufacturing and greener economic growth in China. Third: providing other countries with the cheapest less environmentally-friendly energy sources.

\subsection{The Economic Growth and Transportation Infrastructure}

Numerous economists found that transportation infrastructure has impacts on economic growth. However, some authors found that transportation infrastructure had positive impacts on the economic growth of many countries whilst others found that it had ambiguous, insignificant, or even negative effects on economic growth. Transportation and communication structure may produce both positive and negative benefits in the area where they are located; and positive or negative spillovers to other regions.

Holtz-Eakin and Lovely (1996), stated that transport construction can make an industry to be benefited more as an appositive influence. Moreno et al. (1997) cited that in Spain, in the period (1965-1991), public capital has a greater role in industrial productivity than in any other economic area that was due to processes of growth and liberalization. However, public capital can enlarge the accessibility of economic organizations and lessen costs by using the economic liberalization that making a possible expansion.

The negative influence of transportation, however, in the case of the above economy: is that the dependence of a region's output on t the standard of transportation infrastructure on other regions. Kelejian and Robinson (1997) and Boarnet (1998) found that this passive impact from transport public capital can be attributed to the fact that one region can draw industrial production away from other regions because of the mobility of the input factor. So, in the initial phases, differences may be increased due to usage of public investment in deepening and integration process since affecting the regions with weak competitive positions.

\section{Methodology and Results Implementation}

\subsection{Foreword in Brief}

To measure the influence of removing physical borders, a quantitative analysis was to be developed to perfect transport facilities across BRI areas. To measure transport facilities and continuity we use a series of broad-based meters and we incorporated them into a gravity model to determine their effect on international trade. First, we provide a brief review on the theoretical related issues of the gravity model then the resulting empirical models with interpretation were explained, and finally possible evidence in transportation facilities continuity was forecast to demonstrate the potential commerce effects for the BRI zones. 


\subsection{The Theorem of the Gravity Model}

As reported by Anderson (2011) and Shepherd (2012), the gravity model is widely used in analyzing commerce patterns and effects (influence). This model was derived from Newton's Universal Law on Gravitation which states that, particles in the space appeal to other elements due to a force that is proportional to the mass of the elements' and inversely proportional to the square of the distance between two things. Hypothetically, commerce between countries is relational to their market size and closeness. Samuelson (1939), stated that the distance and commerce cost are both serious for commerce between states. In 1979, Anderson describes the gravity model by recognizing a set of economic theories and further he made an explanation that consumers have preferences for different goods and commodities are distinguished by source. However, economists assumed that only a portion of transported imports will arrive at their terminus. That is dependence on commerce cost, also known as 'iceberg' costs. have recently been explored by Recently, Anderson and van Wincoop (2003); Arkolakis et al. (2012); and Eaton (2002), have made the economic set ascends originating from the gravity equation. They assume relative trade cost controls two-sided trade flows rather than merely by givens trade costs. The gravity equation formula:

$$
\begin{gathered}
\rho_{a b}=\frac{\alpha_{a} \alpha_{b}}{\alpha}\left(\frac{z_{a b}}{Q_{a} W_{b}}\right)(1-\Re) \\
Q_{a}=\sum_{b=1}^{N}\left(\frac{z_{i j}}{W_{j}}\right)(1-\Re) \frac{\alpha_{j}}{\alpha} \\
W_{b}=\sum_{a=1}^{N}\left(\frac{z_{a b}}{Q_{a}}\right)(1-\Re) \frac{\alpha_{i}}{\alpha}
\end{gathered}
$$

Where $\rho$ ab shows exports from the country a to country b, $\alpha_{a}$ is the GDP of the country a, $\alpha_{b}$ is the GDP of country $\mathrm{b}, \alpha$ is the world's GDP, $\Re$ is the elasticity of substitution among product varieties and $Z_{a b}$ is the bilateral commerce cost of sending products from the country a to country b according to Clark et al. (2004). $\mathrm{Q}_{\mathrm{b}}$ and $\mathrm{W}_{\mathrm{b}}$ show an outward and inward multilateral resistance (multilateral commerce resistance [MTR]), which captures the fact that export from a country a to country $\mathrm{b}$ is determined by commerce costs across all possible export and import markets. A reduction in bilateral commerce cost among China and a third country such as a Central Africa Country-Gabon would reduce China's MTR (Eisenman, 2012). (Even though the bilateral commerce cost between China and CAC remains unchanged, the fall in China's MTR (due to the reduction of commerce cost among China and Central African countries would lead to a diversion of commerce away from China-CAC to commerce among China and Central African countries-Gabon. Failure to account for the multilateral resistance effects would lead to an upward bias in the estimates of gains from the imaginable testaments. Given its multiplicative nature, the gravity equation outlined in (1) can be transformed by taking the logarithms to a log-linear form illustrated as follows:

$$
\ln \rho_{a b}=\ln \alpha_{a}+\ln \alpha_{b}-\ln \alpha+(1-\Re)\left(\ln z_{a b}-\ln Q_{a}-\ln W_{b}\right)
$$

Due to the lack of a direct measure of commerce cost, $Z_{a b}$ is usually specified empirically as a function of observable variables that are seen as directly correlating to commerce cost. In literature, log-linear specification is often applied as follows:

$$
\ln \left(z_{a b}\right)=\beta_{1} \ln \left(D_{a b}\right)+\beta_{2}\left(C O T_{a b}\right)+\beta_{3}\left(C O L_{a b}\right)
$$

Where $\mathrm{D}$ (distance) is the geographical distance between countries a and b, COT categorical variable equal to one if countries share a common land border. COL (colony) is equal to one if countries a and $\mathrm{b}$ had a colonial history. These factors reflect the hypotheses that transport costs become more but are lower for neighboring countries. Indicators for colonial history are related to information cost regarding commerce, where such costs are presumably lower for commerce among countries whose culture and business practices are known to each other.

\subsection{Empirical Method and Documented Data}

The parameters of a gravity model that captures commerce patterns of countries within the BRI area have been projected, and central African countries (CAC) were selected for this research. In total 18 countries were included in the model (8 BRI countries/areas, and 10 central African countries (CAC) among which 5 were chosen). Some states were excepted due to a lack of documented information. The detailed state list is shown in Appendix A.

\subsubsection{Baseline Gravity Model}

Anderson and van Wincoop (2003) and Head and Mayer (2000) put forward a structural specification of the 
model; that is to capture the many-sided resistance result. Normally, convergence is often difficult for the non-linear calculation involved and can be responsive to the initial choice of parameters. A simple but successful solution that takes a linear approximation (by a first-order Taylor sequence expansion) of the multilateral resistance clause is suggested and advised by Baier and Bergstrand (2009) to avoid the difficulty involved in the non-linear procedure in the mentioned model.

$$
\begin{array}{r}
\ln Q_{a}=\left[\sum_{b=1}^{N} O_{b} \ln \left(z_{a b}\right)-\frac{1}{2} \sum_{Q=1}^{N} \sum_{m=1}^{N} O_{k} O_{m} \ln \left(z_{k m}\right)\right] \\
\ln W_{a}=\left[\sum_{b=1}^{N} O_{b} \ln \left(z_{a b}\right)-\frac{1}{2} \sum_{Q=1}^{N} \sum_{m=1}^{N} O_{k} O_{m} \ln \left(z_{k m}\right)\right]
\end{array}
$$

Substituting equations (6)and (7) into equation (3), we then get:

$$
\begin{gathered}
\ln \rho_{a b}=\ln \alpha_{a}+\ln \alpha_{b}-\ln \alpha+(1-\Re)\left(\ln z_{a b}^{*}\right) \\
\ln z_{a b}{ }^{\prime}=\ln z_{a b}-\sum_{b=1}^{N} O_{b} \ln \left(z_{i j}\right)-\sum_{a=1}^{N} O_{a} \ln \left(z_{a b}\right)-\sum_{Q=1}^{N} \sum_{m=1}^{N} O_{Q} O_{m} \ln \left(t_{Q m}\right)
\end{gathered}
$$

The GDP share of the country ( $\mathrm{k}$ and $\mathrm{m}$ ) refers to the country pairs in the research; this has been demonstrated in the following equations. Any transport index is defined using an equation to account for the MTR (10). For example, the distance variable of the roadway is included in the model as:

$$
\begin{gathered}
\ln \left((\text { air + road + shipping })_{a b}{ }^{\prime}\right)=\ln \left((\text { air }+ \text { road + shipping })_{a b}\right)-\sum_{b=1}^{N} w_{b} \ln \left((\text { air }+ \text { road + shipping })_{a b}\right)- \\
\sum_{a=1}^{N} O_{a} \ln \left((\text { air + road + shipping })_{a b}\right)-\sum_{Q=1}^{N} \sum_{m=1}^{N} O_{Q} O_{m} \ln \left((\text { air + road + shipping })_{Q m}\right)
\end{gathered}
$$

In this way, the change in the road distance can affect the commerce between the two The relative size of the exporters/importers is also used to calculate the MTR. Our research hypothesis is that transport basic facilities and multi-modal continuity among countries affect (influence) the commerce cost $Z_{a b}$, and also on the bilateral trade. The specification of trade cost is hence estimated as follows:

$$
\begin{aligned}
& \ln \left(t_{i j}^{\prime}\right)=\beta_{1 \text { maritime }} \ln \left(\text { maridist }_{i j}^{\prime}\right)+\beta_{2} \ln \left(\text { air_dist }_{i j}^{\prime}\right)+\beta_{3} \ln \left(\text { road_density }_{i j}^{\prime}\right)+\beta_{4} \ln \left(\text { airportden }_{i j}^{\prime}\right) \\
& +\beta_{5} \ln \left(\log \text { istic }_{i j}^{\prime}\right)+\beta_{6} \ln \left(\text { tarrif }_{i j}^{\prime}\right)+\beta_{7}\left(\text { contig }_{i j}\right)+\beta_{8}\left(\text { colony }_{i j}\right)
\end{aligned}
$$

Equation (11) was used to specify transport facilities consistency such as seaport and sea transport for maritime (Nikkei Asian Review. 2016.) consistency, road consistency, and airport consistency), transport continuity, that is, seaport and sea transport for maritime. The distance with 'No Link term for (sea, air, and road transport). The documented information foundation was discussed using parameters estimated from the gravity model, thus predicted the effect (influence) of a change in one or more of these variables on the bilateral commerce (counterfactual analysis). The static geographical variables coting and colony; hence, they were kept as simple Clause as in the above gravity model.

\subsection{Written Down Information}

Standard documented data sources were used in the gravity model. Table 1 fully summarizes the bilateral commerce from COM-commerce, that considered the most public source of documented data on disaggregated commerce by a good. Documented data from 2013 was used in the research. Commerce values in US\$ were converted from national currencies. Documented data (information) were also available through the United Nations website (UN COM-commerce 2015-2018). Documented data (information) on GDP was from the World Bank expands Indicator information database (World Bank 2018). Documented information on bilateral tariff from United Nations Conference Trade and Development (UNCTAD) ships database. Tariff rates as effective bilateral rates take into account area and preferential agreements and the average was calculated by adding commercial weights for a few countries. We have imputed 2014 values in these situations. The following sections discuss the sources of transportation facilities and steadiness measurements. 
Table 1. Written down data (information) sources for the gravity model (2016)

\begin{tabular}{|c|c|c|c|}
\hline & Variable & Description & Source \\
\hline \multirow{5}{*}{$\begin{array}{l}\text { Economic } \\
\text { indices }\end{array}$} & Exports & Total exports from the country a to country $\mathrm{j}$ & UN COM-commerce \\
\hline & GDP & Nominal GDP in US\$ & World expand Indicators \\
\hline & Tariff rate & $\begin{array}{l}\text { Effectively applied tariff, commerce weighted } \\
\text { average }\end{array}$ & $\begin{array}{l}\text { ships via UN Conference on Trade } \\
\text { and Development (UNCTAD) }\end{array}$ \\
\hline & Airports & The number of primary and secondary airports & CIA World Fact-book \\
\hline & $\begin{array}{l}\text { maritime(seaport and sea } \\
\text { transport) consistency }\end{array}$ & Road network length/land area of the country & CIA World Fact-book \\
\hline \multirow{5}{*}{$\begin{array}{l}\text { Transport basic } \\
\text { facilities } \\
\text { indicators }\end{array}$} & $\begin{array}{l}\text { maritime(seaport and sea } \\
\text { transport) consistency }\end{array}$ & $\begin{array}{l}\text { maritime(seaport and sea transport) network } \\
\text { length/land area of the country }\end{array}$ & CIA World Fact-book \\
\hline & Logistics performance & $\begin{array}{l}\text { LPI score on the competence and good or bad } \\
\text { quality of logistics services }\end{array}$ & World Bank \\
\hline & Maritime transport & $\begin{array}{l}\text { Linear Shipping Index (LSI) score on the } \\
\text { competence and good or bad quality of logistics } \\
\text { services }\end{array}$ & $\begin{array}{l}\text { United Nations } \\
\text { Trade and } \\
\text { (UNCTAD) }\end{array}$ \\
\hline & Air transport distance & $\begin{array}{l}\text { The bilateral air distance among the capitals of } \\
\text { country pairs }\end{array}$ & Rome2rio \\
\hline & $\begin{array}{l}\text { maritime(seaport and sea } \\
\text { transport) and road } \\
\text { distance }\end{array}$ & $\begin{array}{l}\text { The bilateral (In our case sea, air, and road } \\
\text { transport) and road distance among the capitals } \\
\text { of the country pair }\end{array}$ & Rome2rio and Google Maps \\
\hline \multirow{2}{*}{$\begin{array}{l}\text { Transport } \\
\text { continuity }\end{array}$} & $\begin{array}{l}\text { Without (In our case sea, } \\
\text { air and road transport) } \\
\text { link }\end{array}$ & $\begin{array}{l}\text { The indicator variable that equals unity if there } \\
\text { is no direct (In our case sea, air, and road } \\
\text { transport) link among the capitals of country } \\
\text { pairs }\end{array}$ & Rome2rio and Google Maps \\
\hline & Maritime distance & $\begin{array}{l}\text { The maritime distance among the capitals of the } \\
\text { country pair }\end{array}$ & CERDI sea distance \\
\hline \multirow[t]{2}{*}{ Distance } & Distance & $\begin{array}{l}\text { The bilateral distance among the capitals of } \\
\text { country pairs - not differentiated by mode }\end{array}$ & $\begin{array}{l}\text { CEPII Geo-Dist written down data } \\
\text { (information)base }\end{array}$ \\
\hline & Colony & $\begin{array}{l}\text { Dummy variable equal to unity if one economy } \\
\text { was once a colony of the other }\end{array}$ & $\begin{array}{l}\text { CEPII Geo-Dist written down data } \\
\text { (information)base }\end{array}$ \\
\hline Other controls & Common border & $\begin{array}{l}\text { Dummy variable equal to unity for economies } \\
\text { that share a common land border }\end{array}$ & $\begin{array}{l}\text { CEPII Geo-Dist written down data } \\
\text { (information)base }\end{array}$ \\
\hline
\end{tabular}

\subsubsection{Descriptive Analytical}

Table 2 provides a descriptive analysis of documented economic data (information) for the BRI, and central African countries (CAC). We observed a great extent of variation of GPD and exports within each area. For instance, in the BRI area, the CAC has the lowest GDP in 2013 at US\$1.76 million while China has the highest at US\$9.61 trillion, below AVRG stands for average.

Table 2. Economic written down data (information) descriptive-analytical by area

\begin{tabular}{|c|c|c|c|c|c|}
\hline GDP (US\$ MILLION) & Maximum & & Minimum & & AVRG \\
\hline BRI & $8.52 \times 10^{\wedge} 6$ & $\mathrm{CHN}$ & $0.01 \times 10^{\wedge} 6$ & MODEL1 & $0.54 \mathrm{X} 10^{\wedge} 6$ \\
\hline CAC & 1.76 & $\mathrm{CAC}$ & 0.06 & MODEL2 & 0.35 \\
\hline \multicolumn{6}{|c|}{ commerce values (US\$ MILLION) } \\
\hline BRI & $0.4 \mathrm{X} 10^{\wedge} 6$ & $\mathrm{CHN}$ & & & \\
\hline CAC & 0.1 & NLD & & & \\
\hline \multicolumn{6}{|c|}{ Tariff(US\$) } \\
\hline BRI & $601.84 \mathrm{X} 10^{\wedge} 6$ & $\mathrm{CHN}$ & & MODEL3 & $5.12 \times 10^{\wedge} 6$ \\
\hline CAC & 13.6 & $\mathrm{CAC}$ & & MODEL4 & 1.98 \\
\hline
\end{tabular}

\subsubsection{Model Boundlessness}

A major limitation of gravity models is that they focus on commerce capacity and do not show the indirect 
linkages among various elements in economies for different sectors at a more dis-aggregated standard (Walker et al., 2009). Unlike computable general equilibrium (CGE) models, which provide explicit links in changing production-consumption pattern and changes to commerce, the gravity model can only identify static effects transport facilities on bilateral commerce, keeping all other factors constant (i.e. it generates first-order effect commerce (Plummer et al., 2011). It also does not explicitly take into account the balance among supply-demand for goods, services, as well as production in the long term. More so, how firms and households respond to changes in transport costs were not accounted for. In applying the gravity model outlined in equation (9), changes in patterns of bilateral commerce capacity as a result of transport continuity, tariffs, and other commerce characteristics, such as the presence of a common border, and historical antecedents were the only metric observed. Tables 3 and 4 show the Descriptive statistics on the export and Trade Flow of China and Sub-Saharan Africa products. As such, results from the empirical model show the relationship between transport cost and bilateral commerce. In addition, all the variables that influence commerce flows and commerce barriers may not be addressed in the empirical model. By controlling many variables such as documented data or information and incorporating multilateral resistance clauses issues hindering commerce flows or commerce barriers may be mitigated.

Table 3. Descriptive statistics on exports and trade flow China and Sub-Saharan Africa product: 2016

\begin{tabular}{|c|c|c|c|c|c|}
\hline Product Group & $\begin{array}{c}\text { Export } \\
\text { (US\$ Thousand) }\end{array}$ & $\begin{array}{c}\text { Export Product } \\
\text { Share }(\%)\end{array}$ & $\begin{array}{c}\text { Revealed comparative } \\
\text { advantage }\end{array}$ & $\begin{array}{c}\text { World Growth } \\
(\%) \\
\end{array}$ & $\begin{array}{c}\text { Country } \\
\text { Growth }(\%)\end{array}$ \\
\hline All Products & $64,069,550.85$ & 100.00 & & & \\
\hline Consumer goods & $29,278,096.16$ & 45.70 & & - & - \\
\hline Capital goods & $18,932,165.73$ & 29.55 & - & - & - \\
\hline Mach and Elec & $17,233,373.52$ & 26.90 & & & \\
\hline Intermediate goods & $15,271,725.52$ & 23.84 & & & \\
\hline Textiles and Clothing & $12,220,020.10$ & 19.07 & & & \\
\hline Metals & $7,202,422.27$ & 11.24 & & & \\
\hline Transportation & $4,664,140.14$ & 7.28 & & & \\
\hline Miscellaneous & $4,172,876.79$ & 6.51 & & & \\
\hline Footwear & $3,877,413.42$ & 6.05 & & & \\
\hline Plastic or Rubber & $3,709,619.12$ & 5.79 & & & \\
\hline Chemicals & $3,277,324.38$ & 5.12 & & & \\
\hline Stone and Glass & $2,460,890.25$ & 3.84 & & & \\
\hline Wood & $1,596,718.09$ & 2.49 & & & \\
\hline Hides and Skins & $957,613.19$ & 1.49 & & & \\
\hline Food Products & $911,551.71$ & 1.42 & & & \\
\hline Fuels & $674,416.57$ & 1.05 & & & \\
\hline Vegetable & $561,201.52$ & 0.88 & & & \\
\hline Raw materials & $511,419.03$ & 0.80 & & & \\
\hline Animal & $384,291.14$ & 0.60 & & & \\
\hline Minerals & $165,678.66$ & 0.26 & & & \\
\hline
\end{tabular}

Table 4. Descriptive statistics on exports and trade flow China and Sub-Saharan Africa product: 2018

\begin{tabular}{|c|c|c|c|c|c|}
\hline Product Group & Export (US\$ Thousand) & $\begin{array}{c}\text { Export Product } \\
\text { Share }(\%)\end{array}$ & $\begin{array}{c}\text { Revealed comparative } \\
\text { advantage }\end{array}$ & $\begin{array}{c}\text { World Growth } \\
(\%)\end{array}$ & Country Growth (\%) \\
\hline All Products & $74,716,777.38$ & 100.00 & & & \\
\hline Consumer goods & $32,669,898.86$ & 43.73 & & & \\
\hline Capital goods & $21,630,698.88$ & 28.95 & & & \\
\hline Intermediate goods & $19,764,546.43$ & 26.45 & & & \\
\hline Mach and Elec & $18,852,632.72$ & 25.23 & & & \\
\hline Textiles and Clothing & $13,192,897.90$ & 17.66 & & & \\
\hline Metals & $9,452,518.17$ & 12.65 & & & \\
\hline Transportation & $5,780,285.62$ & 7.74 & & & \\
\hline Plastic or Rubber & $4,899,346.07$ & 6.56 & & & \\
\hline Miscellaneous & $4,639,712.54$ & 6.21 & & & \\
\hline
\end{tabular}




\begin{tabular}{lcl}
\hline Chemicals & $4,586,108.43$ & 6.14 \\
Footwear & $4,363,639.97$ & 5.84 \\
Stone and Glass & $2,560,854.40$ & 3.43 \\
Wood & $1,610,340.22$ & 2.16 \\
Fuels & $1,283,690.57$ & 1.72 \\
Food Products & $1,073,323.88$ & 1.44 \\
Hides and Skins & $1,016,162.10$ & 1.36 \\
Vegetable & $840,064.16$ & 1.12 \\
Raw materials & $629,419.89$ & 0.84 \\
Animal & $511,590.12$ & 0.68 \\
Minerals & $53,610.49$ & 0.07 \\
\hline
\end{tabular}

\subsection{Empirical Results}

\subsubsection{Model Estimation}

In the first phase, parameters of the gravity model in equation (9) were estimated with Ordinary Least Squares (OLS) and Poisson Pseudo-Maximum Likelihood (PPML) estimators (Silva, 2006), taking into account clustering error clause within groups. Moulton (1990), emphasized that failure to identify clustering could result in understated standard errors that are more likely to be correlated by country pair. The model estimation that specifies transport facilities and linked variables interest using equation (10) involved an MTR clause. The PPML approach which uses a quasi-Poisson distribution and log-link is a generalized linear method for estimating gravity. With this method, zero commerce flows are allowed in the estimation. However, in the OLS approach, we added unity to the commerce values that were equal to zero to avoid the zero commerce flows being dropped (as a transformed logarithmic form). The model results are shown in Table 5. Models 1 and 2 are baseline gravity models containing distanced, tariff, and other control variables. Most of the clauses were importantly estimated with the expected sign in models 1 and 2. The relationship between the distance among trading partners and commerce flow was estimated. The greater the distance among the trading partners, the smaller the commerce flows. As such distance and clauses were negatively estimated. For both OLS and PPML methods, the distance was a commerce deterrent, although the elasticity is smaller in the PPML model. There is a positive effect on export flows for countries with a common border and as well as those with colonial history. The estimated parameters containing transport continuity (distance by mode) and transport facilities quantity and service the model shows in models 3 and 4. Between the OLS and PPML methods, the signs of the estimates do not differ except for the tariff term, which is (incorrectly) positively estimated in the OLS model.

Table 5. Preferred econometric results from the gravity model

\begin{tabular}{|c|c|c|c|c|c|c|c|c|}
\hline & Model_1 & Model_2 & Model_3 & Model_4 & & & & \\
\hline Estimated Method & OLS & PPML & OLS & PPML & & & & \\
\hline Dependent Variable & $\log ($ exports +1$)$ & Exports & $\log ($ exports +1$)$ & Exports & & & & \\
\hline Description & coef. & t-value & coef. & t-value & coef. & t-value & coef. & $\mathrm{t}$-value \\
\hline Exporter GDP & 0.765 & 69.52 & 0.487 & 30.11 & 0.5 & 50.22 & 0.4 & 36.78 \\
\hline Importer GDP & 0.627 & 49.07 & 0.498 & 40.01 & 0.199 & 19.87 & 0.398 & 40.01 \\
\hline Distance14 & -2.083 & -74.99 & -0.757 & -17.9 & & & & \\
\hline $\begin{array}{l}\text { No (In our case sea, air and road } \\
\text { transport) link (constant) }\end{array}$ & & & & & -0.899 & -8.01 & -0.598 & -2.96 \\
\hline Air distance & & & & & -0.901 & -8.01 & -0.398 & -5.01 \\
\hline \multirow[t]{2}{*}{ Maritime distance } & & & & & -0.398 & -6.06 & -0.098 & -1.97 \\
\hline & & & & & 18.526 & 15.69 & 0.417 & 4.41 \\
\hline
\end{tabular}

\section{Summary and Conclusions}

Research has shown that multi-modal transport facilities and continuity are critical for promoting international commerce and economic growth. More specifically, well reduce costs facilitate expansion Snyder et al. (2012).

The efficient industrialization process enables more efficient area and global production networks, supports integration, and fosters the expansion of national welfare. This research identified and discussed the physical and soft barriers/facilitators relating to transport continuity and commerce more generally in the BRI area. The 
physical barriers/facilitators include an inadequate capacity of equipment, speed and cost of transporting goods, and inhospitable terrain. The soft barriers/facilitators include legal and regulatory barriers, project financing, security, tracking of goods as well as security surrounding commerce routes (Abe et al., 2009). Building upon the qualitative analysis, the following hypothesis was formed: that removing the physical barriers (by perfecting continuity) would facilitate commerce and have a broader positive effect (influence) on economic growth in the BRI area. To examine the research hypothesis, a gravity model was developed to test the relevance among transport continuity and commerce. First, a series of indices were developed to measure transport facilities (containing sea, air, road transport)/road consistency, airport logistics performance) using distance by different modes as proxy journey cost. Countries in the BRI area and central African (CAC) countries were included. The descriptive-analysis of transport measures were:

1) Transport facilities in the BRI area focused on the sea, air, and road transport consistency, as well as airport consistency.

2) Within the BRI area, the standard of transport facilities across countries vary. It was observed that some South and West Asian countries suffered from poor sea, air, and road transport facility continuity among and there was relatively low road/maritime (seaport and sea transport) consistency in some areas. The models were developed to estimate bilateral commerce within the research area and to determine the relative commerce cost among trading countries, thus the MTR clause modeling framework was also used. A positive relevance among transport facilities, continuity, and bilateral commerce was developed. Additionally, having a (sea, air, and road transport) link in the BRI area, consequently gives the biggest scale influence on perfecting commerce (perfecting total exports by $0.08 \%$ in the research area). Logistics performance (for instance LPI) also showed an important and relatively strong influence on bilateral commerce flows.

\section{References}

Abe, K., \& John, S. W. (2009). Weathering the Storm: Investing in port basic facilities to lower commerce costs in East Asia. Policy Research Working Paper 4911, World Bank. https://doi.org/10.1596/1813-9450-4911

Anderson, J. E. (2011). The gravity model. Annu. Rev. Econ., 3(1), 133-60. https://doi.org/10.1146/annurev-economics-111809-125114

Anderson, J. E., \& Van, W. E. (2003). Gravity with gravitas: A solution to the border puzzle. American Economic Review, 93(1), 170-92. https://doi.org/10.1257/000282803321455214

Arkolakis, C., Costinot, A., \& Rodríguez-Clare, A. (2012). New trade models, same old gains? American Economic Review, 102(1), 94-130. https://doi.org/10.1257/aer.102.1.94

Bagwandeen, M. (2017). The African Link in China's OBOR Initiative. CCS Commentary.

Baier, S. L., \& Bergstrand, J. H. (2009). Bonus Vetus OLS: A simple method for approximating international trade-cost effects using the gravity equation. Journal of International Economics, 77(1), 77-85. https://doi.org/10.1016/j.jinteco.2008.10.004

Boarnet, M. G. (1998). Spillovers and the locational effects of public infrastructure. Journal of Regional Science, 38(3), 381-400. https://doi.org/10.1111/0022-4146.00099

Chen, W., \& Nord, R. (2017). A Rebalancing Act for China and Africa The Effects of China's Rebalancing on Sub Saharan Africa's Trade and Growth. International Monetary Fund, Washington, DC.

Clark, X., Dollar, D., \& Micco, A. (2004). Port efficiency, maritime transport costs, and bilateral trade. Journal of Development Economics, 75(2), 417-50. https://doi.org/10.1016/j.jdeveco.2004.06.005

Das, K. C. (2017). The Making of One Belt, One Road, and Dilemmas in South Asia. China Report, 53(2), 125-142. https://doi.org/10.1177/0009445517696624

Eaton, J., \& Kortum, S. (2002). Technology, geography, and trade. Econometrica, 70(5), 1741-79. https://doi.org/10.1111/1468-0262.00352

Eisenman, J. (2012). China-Africa trade patterns: causes and consequences. Journal of Contemporary China, 21(77), 793-810. https://doi.org/10.1080/10670564.2012.684964

Gazeta Wyborcza. (2018). Kiedy Afryka wystrzeli w górę. Rozmowa z Reinerem Klingholzem (przeprowadził Michał Kokot). Gazeta Wyborcza, p. 8.

Glaeser, E. L., \& Kohlhase, J. E. (2004). Cities, regions and the decline of transport costs. In fifty years of regional science (pp. 197-228). Springer, Berlin, Heidelberg. https://doi.org/10.1007/978-3-662-07223-3_9 
Head, K., \& Mayer, T. (2000). Non-Europe: The magnitude and causes of market fragmentation in the EU. Review of World Economics, 136(2), 284-314. https://doi.org/10.1007/BF02707689

Hummels, D. (2007). Transportation costs and international trade in the second era of globalization. Journal of Economic Perspectives, 21(3), 131-54. https://doi.org/10.1257/jep.21.3.131

Hummels, D. L. (1999).Toward a geography of trade costs. https://doi.org/10.2139/ssrn.160533

Kelejian, H. H., \& Robinson, D. P. (1997). Infrastructure productivity estimation and its underlying econometric specifications: A sensitivity. Papers in Regional Science, 76(1), 115-131. https://doi.org/10.1111/j.1435-5597.1997.tb00684.x

Lim, K. S. (2018). China's Arctic Policy and the Polar Silk Road Vision. Arctic Yearbook, 420-32.

Limao, N., \& Venables, A. J. (2001). Infrastructure, geographical disadvantage, transport costs, and trade. The World Bank Economic Review, 15(3), 451-79. https://doi.org/10.1093/wber/15.3.451

Lu, H., Charlene, R., Marco, H., \& Anna, K. (2018). China Belt and Road Initiative: Measuring the Impact of Improving Transportation Connectivity on Trade in the Region. RAND Corporation. https://doi.org/10.7249/RR2625

Ministry of the Commerce People's Republic of China. (2018). Statistics on China-Africa Bilateral Trade in 2017. Retrieved from http:/english.mofcom.gov.cn/article/statistic/lanmubb/AsiaAfrica/201803/20180302719613.shtml

Moreno, R., Artís, M., López-Bazo, E., \& Suriñach, J. (1997). Evidence on the complex link between infrastructure and regional growth. International Journal of Development Planning Literature, 12(1\&2), 81-108.

Moulton, B. R. (1990). An Illustration of a Pitfall in Estimating the Effects of Aggregate Variables on Micro Units. The Review of Economics and Statistics, 72, 334-338. https://doi.org/10.2307/2109724

Nikkei Asian Review. (2016). Jakarta-Bandung High-speed (In our case sea, air, and road transport) Project Stalls. Retrieved from http://www.Asia.nikkei.com

Plummer, M. G., Cheong, D., \& Hamanaka, S. (2011). Methodology for impact assessment of free trade agreements. Asian Development Bank.

Prospects, G. E. (2018). The Turning of the Tide. The World Bank website. Retrieved from http://www.worldbank.org/en/publication/global-economic-prospects

Redding, S. J., \& Turner, M. A. (2015). Transportation costs and the spatial organization of economic activity. Handbook of Regional and Urban Economics, 5, 1339-1398. https://doi.org/10.1016/B978-0-444-59531-7.00020-X

Rolland, N. (2017). China's "Belt and Road Initiative": Underwhelming or game-changer? The Washington Quarterly, 40(1), 127-42. https://doi.org/10.1080/0163660X.2017.1302743

Shepherd, B. (2012). The Gravity Model of International Trade. A User Guide, ESCAP.

Silva, J. S., \& Tenreyro, S. (2006). The log of gravity. The Review of Economics and Statistics, 88(4), 641-58. https://doi.org/10.1162/rest.88.4.641

Snyder, J. D., Corey, K. E., Snyder, M., Doyle, K., \& Gepper, J. (2012). A global review of innovative practices in regional SME exporting strategies and foreign direct investment attraction. Center for Community and Economic Development, MI State University.

UN COM-commerce. Report 2015-2018.

Walker, J., \& Unger, B. (2009). Measuring Global Money Laundering: The Walker Gravity Model. Review of Law \& Economics, 5(2), 821-53. https://doi.org/10.2202/1555-5879.1418

Wilson, J. S., \& Otsuki, T. (2007). Regional integration in South Asia: What role for trade facilitation? The World Bank. https://doi.org/10.1596/1813-9450-4423

Xianfa. (2018). Initiating 'a golden era' for China-Kenya Cooperation. Retrieved from https://eng.yidaiyilu.gov.cn/ghsl/wksl/53479.htm 


\section{Appendix}

Table A1. Descriptive statistics on import and exports and trade flow China and Sub-Saharan Africa product: 2016

\begin{tabular}{|c|c|c|c|c|c|c|c|c|c|c|c|c|c|}
\hline Product Group & $\begin{array}{l}\text { Export (USs } \\
\text { Thousand) }\end{array}$ & $\begin{array}{l}\text { Import (USs } \\
\text { Thousand) }\end{array}$ & $\begin{array}{c}\text { Export } \\
\text { Product } \\
\text { Share (\%) }\end{array}$ & $\begin{array}{l}\text { Import } \\
\text { Product } \\
\text { Share (\%) }\end{array}$ & $\begin{array}{c}\text { Revealed } \\
\text { comparative } \\
\text { advantage }\end{array}$ & $\begin{array}{c}\text { World } \\
\text { Growth } \\
(\%)\end{array}$ & $\begin{array}{l}\text { Country } \\
\text { Growth } \\
(\%)\end{array}$ & $\begin{array}{c}\text { Aims } \\
\text { Simple } \\
\text { Average } \\
(\%)\end{array}$ & $\begin{array}{l}\text { AAs } \\
\text { Weighted } \\
\text { Averagae } \\
\text { (\%) }\end{array}$ & $\begin{array}{c}\text { AHS Total } \\
\text { Tariff } \\
\text { Lines }\end{array}$ & $\begin{array}{c}\text { AHs } \\
\text { Dutiable } \\
\text { Tariff } \\
\text { Lines } \\
\text { Share } \\
(\%) \\
(\%)\end{array}$ & $\begin{array}{l}\text { AHS } \\
\text { Duty } \\
\text { Froe } \\
\text { Tariff } \\
\text { Lines } \\
\text { Share } \\
\text { (\%) }\end{array}$ & $\begin{array}{c}\text { AHS } \\
\text { Specific } \\
\text { Tariff } \\
\text { Lines } \\
\text { Share } \\
(\%)\end{array}$ \\
\hline All Products & $64,069,550.85$ & $54,262,001.14$ & 100.00 & 100.00 & & & & 5.68 & 1.17 & 12,945 & 49.61 & 49.94 & 0.45 \\
\hline $\begin{array}{l}\text { Consumer } \\
\text { goods }\end{array}$ & $29,278,096.16$ & $638,416.29$ & 45.70 & 1.18 & & & & 8.22 & 7.13 & 4,575 & 55.45 & 44.55 & 0.00 \\
\hline Capital goods & $18,932,165.73$ & $80,244.19$ & 29.55 & 0.15 & & & & 3.58 & 6.09 & 2,786 & 47.24 & 52.76 & 0.00 \\
\hline Mach and Elec & $17,233,373.52$ & $41,878.28$ & 26.90 & 0.08 & & & & 3.29 & 3.27 & 2,230 & 42.11 & 57.89 & 0.00 \\
\hline $\begin{array}{l}\text { Intermediate } \\
\text { goods }\end{array}$ & $15,271,725.52$ & $19,778,214.04$ & 23.84 & 36.45 & & & & 5.49 & 1.90 & 3,010 & 53.46 & 45,35 & 1.20 \\
\hline $\begin{array}{l}\text { Textiles and } \\
\text { Clothing }\end{array}$ & $12,220,020.10$ & $385,239.34$ & 19.07 & 0.71 & & & & 8.37 & 14.33 & 3.088 & 54.63 & 45.37 & 0.00 \\
\hline Metals & $7,202,422.27$ & $5,829,673,40$ & 11.24 & 10.74 & & & & 5.98 & 1.62 & 678 & 73.01 & 26.99 & 0.00 \\
\hline Transportation & $4,664,140.14$ & $33,621.99$ & 7.28 & 0.06 & & & & 7.60 & 9.67 & 323 & 76.54 & 24.46 & 0.00 \\
\hline Miscellaneous & $4,172,876.79$ & $11,258.49$ & 6.51 & 0.02 & & & & 6.01 & 6.14 & 765 & 46.41 & 53.59 & 0.00 \\
\hline Footwear & $3,877,413.42$ & $18,345.64$ & 6.05 & 0.03 & & & & 9.57 & 3.48 & 99 & 52.53 & 47.47 & 0.00 \\
\hline $\begin{array}{l}\text { Plastic or } \\
\text { Rubber }\end{array}$ & $3,709,619.12$ & 139,612.60 & 5.79 & 0.26 & & & & 7.10 & 10.38 & 342 & 69.59 & 30.41 & 0.00 \\
\hline Chemicals & $3.277,324.38$ & $323,108.56$ & 5.12 & 0.60 & & & & 7.22 & 5.65 & 787 & 88.31 & 11.69 & 0.00 \\
\hline $\begin{array}{l}\text { Stone and } \\
\text { Glass }\end{array}$ & $2,460,890.25$ & $14,053,221.55$ & 3.84 & 25.90 & & & & 8.21 & 2.20 & 281 & 61.21 & 38.79 & 0.00 \\
\hline Wood & $1,596,718.09$ & $2,153.822 .23$ & 2.49 & 3.97 & & & & 2.10 & 0.03 & 1,864 & 16.26 & 80.63 & 3.11 \\
\hline $\begin{array}{l}\text { Hides and } \\
\text { Skins }\end{array}$ & 957,613.19 & 196,639.41 & 1.49 & 0.36 & & & & 7.36 & 4.61 & 372 & 63.98 & 36.02 & 0.00 \\
\hline Food Products & $911,551.71$ & $891,494.04$ & 1.42 & 1.64 & & & & 14.61 & 9.67 & 206 & 81.55 & 18.45 & 0.00 \\
\hline Fuels & $674,416.57$ & $20,885,506.39$ & 1.05 & 38.49 & & & & 2.73 & 0.05 & 84 & 61.90 & 38.10 & 0.00 \\
\hline Vegetable & $561,201.52$ & $1,178,167.97$ & 0.88 & 2.17 & & & & 7.26 & 2.07 & 882 & 62.93 & 37.07 & 0.00 \\
\hline Raw materials & $511,419.03$ & $33,764,062,12$ & 0.80 & 62.22 & & & & 2,94 & 0.54 & 2,262 & 34.53 & 64.50 & 0.97 \\
\hline Animal & $384,291.14$ & $95,101.83$ & 0.60 & 0.18 & & & & 4.01 & 2.61 & 446 & 32.06 & 67.94 & 0.00 \\
\hline Minerals & 78. & 25,309 & 0.26 & 14.7 & & & & 0.60 & 0.03 & 498 & 17.27 & 82.73 & 0.00 \\
\hline
\end{tabular}

Table A2. Descriptive statistics on import and exports and trade flow China and Sub-Saharan Africa product: 2018

\begin{tabular}{|c|c|c|c|c|c|c|c|c|c|c|c|c|c|}
\hline Product Group & $\begin{array}{l}\text { Export (USS } \\
\text { Thousand) }\end{array}$ & $\begin{array}{l}\text { Import (USs } \\
\text { Thousand) }\end{array}$ & $\begin{array}{c}\text { Export } \\
\text { Product } \\
\text { Share (\%) }\end{array}$ & $\begin{array}{c}\text { Import } \\
\text { Product } \\
\text { Share (\%) }\end{array}$ & $\begin{array}{c}\text { Revealed } \\
\text { comparative } \\
\text { advantage }\end{array}$ & $\begin{array}{l}\text { World } \\
\text { Growth } \\
(\%)\end{array}$ & $\begin{array}{l}\text { Country } \\
\text { Growth } \\
(\%)\end{array}$ & $\begin{array}{c}\text { AHS } \\
\text { Simple } \\
\text { Average } \\
\text { (\%) }\end{array}$ & $\begin{array}{c}\text { AHS } \\
\text { Weighted } \\
\text { Average } \\
(\%)\end{array}$ & $\begin{array}{c}\text { AHS Total } \\
\text { Tariff } \\
\text { Lines }\end{array}$ & $\begin{array}{c}\text { AHs } \\
\text { Dutiable } \\
\text { Tariff } \\
\text { Lines } \\
\text { Share }(\%)\end{array}$ & $\begin{array}{l}\text { AHS } \\
\text { Duty } \\
\text { Free } \\
\text { Tariff } \\
\text { Lines } \\
\text { Share } \\
(\%)\end{array}$ & $\begin{array}{c}\text { AHS } \\
\text { Specifif } \\
\text { Tariff } \\
\text { Lines } \\
\text { Share } \\
\text { (\%) }\end{array}$ \\
\hline All Products & $74,716,777.38$ & $89,693,709.88$ & 100.00 & 100.00 & & & & 8.20 & 1.26 & 11,949 & 74.20 & 25.80 & 0.00 \\
\hline $\begin{array}{l}\text { Consumer } \\
\text { goods }\end{array}$ & $32,669,898.86$ & $2,581,865.14$ & 43.73 & 2.88 & & & & 12.44 & 6.06 & 3,087 & 91.84 & 8.16 & 0.00 \\
\hline Capital goods & $21,630,698.88$ & $104,879.56$ & 28.95 & 0.12 & & & & 4.76 & 7.34 & 3,376 & 69.55 & 30.45 & 0.00 \\
\hline $\begin{array}{l}\text { Intermediate } \\
\text { goods }\end{array}$ & $19,764,546.43$ & $22,425,859.15$ & 26.45 & 25.00 & & & & 7.03 & 2.34 & 2,822 & 69.53 & 30.47 & 0.00 \\
\hline Mach and Elec & $18,852,632.72$ & $29,422.02$ & 25.23 & 0.03 & & & & 4.44 & 5.53 & 2,723 & 64.82 & 35.18 & 0.00 \\
\hline $\begin{array}{l}\text { Textiles and } \\
\text { Clothing }\end{array}$ & $13,192,897.90$ & $607,007.01$ & 17.66 & 0.68 & & & & 14.31 & 15.31 & 1,181 & 98.98 & 1.02 & 0.00 \\
\hline Metals & 9.452 .518 .17 & $11,097,013.87$ & 12.65 & 12.37 & & & & 7.99 & 2.57 & 729 & 98.77 & 1.23 & 0.00 \\
\hline Transportation & $5,780,285.62$ & $71,198.96$ & 7.74 & 0.08 & & & & 9.32 & 9.56 & 369 & 99.46 & 0.54 & 0.00 \\
\hline $\begin{array}{l}\text { Plastic or } \\
\text { Rubber }\end{array}$ & $4.899,346.07$ & $153,067.91$ & 6.56 & 0.17 & & & & 9.24 & 11.15 & 395 & 99.24 & 0.76 & 0.00 \\
\hline Miscellaneous & $4,639,712.54$ & 1,794,657.90 & 6.21 & 2.00 & & & & 7.57 & 6.58 & 894 & 66.44 & 33.56 & 0.00 \\
\hline Chemicals & $4,586,108.43$ & $530,486.39$ & 6.14 & 0.59 & & & & 8.95 & 5.96 & 709 & 100.00 & 0.00 & 0.00 \\
\hline Footwear & $4,363,639.97$ & $9,605.24$ & 5.84 & 0.01 & & & & 16.01 & 10.99 & 131 & 100.00 & 0.00 & 0.00 \\
\hline $\begin{array}{l}\text { Stone and } \\
\text { Glass }\end{array}$ & $2,560,854.40$ & $13,624,179.01$ & 3.43 & 15.19 & & & & 12.31 & 2.55 & 340 & 93.53 & 6.47 & 0.00 \\
\hline Wood & $1,610,340.22$ & $2,661,598.07$ & 2.16 & 2.97 & & & & 3.01 & 0.05 & 1,913 & 27.39 & 72.61 & 0.00 \\
\hline Fuels & $1,283,690.57$ & $41,731,391.67$ & 1.72 & 46.53 & & & & 3.85 & 0.16 & 53 & 67.92 & 32.08 & 0.00 \\
\hline Food Products & $1,073,323.88$ & $978,451.63$ & 1.44 & 1.09 & & & & 16.89 & 10.30 & 228 & 98.25 & 1.75 & 0.00 \\
\hline $\begin{array}{l}\text { Hides and } \\
\text { Skins }\end{array}$ & $1,016,162.10$ & $171,959.25$ & 1.36 & 0.19 & & & & 11.08 & 9.34 & 437 & 100.00 & 0.00 & 0.00 \\
\hline Vegetable & $840,064.16$ & $1,247,963.34$ & 1.12 & 1.39 & & & & 11.13 & 8.24 & 931 & 92.59 & 7.41 & 0.00 \\
\hline Raw materials & $629,419.89$ & $62,770,678.59$ & 0.84 & 69.98 & & & & 4.70 & 0.48 & 2,326 & 60.10 & 39.90 & 0.00 \\
\hline Animal & $511,590.12$ & 154.483 .68 & 0.68 & 0.17 & & & & 10.17 & 9.18 & 313 & 86.58 & 13.42 & 0.00 \\
\hline Minerals & $53,610.49$ & $14,831,223.93$ & 0.07 & 16.54 & & & & 2.03 & 0.03 & 603 & 57.55 & 42.45 & 0.00 \\
\hline
\end{tabular}


Table A3. LIST OF CAC countries used

\begin{tabular}{ll}
\hline$\#$ & Country \\
\hline 1 & Gabon \\
2 & Democratic Republic of Congo \\
3 & Central African Republic \\
4 & Chad \\
5 & Congo Republic - Brazzaville \\
\hline
\end{tabular}

\section{Copyrights}

Copyright for this article is retained by the author(s), with first publication rights granted to the journal.

This is an open-access article distributed under the terms and conditions of the Creative Commons Attribution license (http://creativecommons.org/licenses/by/4.0/). 